\title{
Religious Charlatanisms and the Vulgarity of power: A Postcolonial Reading of Bulawayo's We Need New Names
}

\author{
Esther Mavengano \\ Department of English and Media Studies \\ Faculty of Arts, Culture and Heritage Studies \\ Great Zimbabwe University \\ esthermavengano@gmail.com \& emavengano@gzu.ac.zw \\ https//orcid.org: 0000-0002-9360-3334 \\ Doi: https://doi.org/10.46222/pharosjot.102.29
}

\begin{abstract}
The end of British rule in Zimbabwe which happened through a protracted liberation struggle against the white regime was celebrated by many across Africa and beyond. The ascendancy of the late president Robert Gabriel Mugabe to the helm of power brought hope for the economic, religious, linguistic, and socio-political freedoms. The attainment of independence was indeed a moment of celebration after several decades of colonial suppression and brutalities against the indigenous black Zimbabweans. What is most troubling is that the euphoria that was triggered by the attainment of independence in 1980 gradually died as the realities of economic, religious, linguistic and socio-political problems resurfaced. This study seeks to interpret NoViolet Bulawayo's depiction and thematisation of religion and politics in her debut novel We Need New Names. The study mainly focuses on how Bulawayo fictionalises and captures the sordid realities of the religious and socio-political problems that haunt the postcolonial subjects in Zimbabwe under Mugabe's leadership. Postcolonial thoughts from Spivak and Achille Mbembe inform the readings of the text. The fictive landscape that is captured in the selected novel shows the hollowness of flag independence attained in Zimbabwe. The postcolonial period during the reign of Mugabe inscribes conditions of subjectivity and subalternity. The studied text also problematises religion and uncovers charlatanisms of the prophets and traditional healers who are portrayed as the biblical wolves in sheep's cloth exploiting those in distress.
\end{abstract}

Keywords: Religious charlatanism, vulgarity of power, flag independence, subaltern, postcolonial theory

\section{Introduction}

The attainment of independence by Zimbabwe in 1980 brought hope to citizens who had suffered religio-cultural, economic and political suppression. Independence came as a moment of relief, a breakaway from colonial oppression that marginalised and impoverished black majority and benefited only white minority. Yet, the jubilations were short-lived since the postcolonial nation degenerated into socio-political and economic problems in the early1990s (Javangwe, 2014). This disquieting development in Zimbabwean postcolony is highlighted by Mavengano (2020) who posits that the postcolonial era that emerges from a history of colonisation has multiple daunting problems which speak to the tragedy of the postcolonial subjects. Zimbabwe is one of such African states that encounter multiple challenges which sadly affect existential conditions of citizens. It is this context that informs this study, guided by the following principal questions that prime the article:

- What interpretive insights can be gained by exploring thematisation of religion and politics of the postcolony in We need new names from postcolonial theorisations?

- How is power exercised or performed in the studied novel? 


\section{Postcolonial Paradigm}

The analyses are anchored on postcolonial thought. The study draws insights from the works of postcolonial theorists. The Spivakian theorisation of the subaltern subjects and Mbembe's (1992b) notion of 'vulgarity of power' are essential in the interrogation of thematisation of religion and politics in We need new names. The subaltern in this context, are those people who are degraded, violated, muted and marginalised in both political and religious realms of the Zimbabwean society. They are the expendable and zombified citizens who occupy position of otherness and marginality in the socio-political, economic and the religious sphere of the postcolony. In this sense the subaltern groups are kept at the margin terrains of the regimes of power in the postcolonial state. These are pertinent insights that can be used to examine socio- political and religious exploitative and oppressive practices which should be challenged.

\section{Synopsis of We need new names.}

NoViolet Bulawayo is a Zimbabwean female writer based in America. Her narrative follows the life of Darling, who at the beginning of the novel is a ten-year old girl living in a slum ironically named Paradise. Darling and her friends from Paradise languish in poverty to the extent that they steal guavas from a rich neighbourhood to feed themselves most of the time. The novel is set in both America and Zimbabwe. Darling who is the protagonist leaves Zimbabwe in the midst of economic and political crises and follows her aunt Fostalina who lives in America. , Fostalina, for her education. Darling and others of her kind find that America is home to Americans, not outsiders. Darling just like many other Zimbabweans who fled from a hostile homeland realised the falsity of the view that America (diaspora) is a land of milk and honey. They find America's cold reception repulsive and shocking. Though the Zimbabwean setting is not explicitly stated in this novel, the textual details support this interpretation of space and location. The novel has received remarkable international attention, winning the Los Angeles Times Booker and Inaugural Elisalat Prizes in 2013, the same year it was published

\section{Religious figures in sheep's cloth}

Religious figures in the novel We need new names are metonymic characters whose presence in the text serve to articulate religious charlatanisms, egocentric attitudes and corrupt behaviour. Religion stupefies people are already in economic and socio-political distress. The precariat are further victimised false Christian prophets like Prophet Bitchngton Mborro and self-proclaimed traditional healers who demand payment in forex. Through the character of Mborro, the church is not the sanctuary for those in economic, socio-political distress. The prophet has uncontrollable carnal weaknesses which make him touches the "woman's thing" in the presence of the congregants. The Paradise citizens such as mother of Bones symbolise zombified Christians who are further victimised by egocentric prophets. The man of the cloth Prophet Bitchngton Mborro in We need new names brainwashes, deceives and exploits his gullible and passivized followers who are uncritical of the prophet's corrupt behaviour in the church. The description of the prophet's actions is laden with sexual insinuations as evidence of his immoral nature. He is a quack who resembles the character of Jero in Soyinka's (1964) The Trials of Brother Jero. Both Jero and his fictive colleague Mborro, view prophethood as a money-syphoning activity. The prophet is a wolf in sheep's cloth that violates the subaltern woman in church. Prophet Bitchngton Mborro's shameless behaviour in the present of congregates magnifies the level of religious charlatanism in the church. His crooked nature symbolically thematises fake Christian religion. Thus, the novel ridicules the church and its followers by exposing the appalling levels of dishonesty even in religious fraternity.

The novelist deploys satirical elements to unmask, mock and condemn ills that pervade the religious and political facets in post-independent Zimbabwe. Desperate citizens search for supernatural intercession with the hope to get solutions to the multiple problems they encounter. Unfortunately, the unwary citizens are victimised by religious charlatans and bigots who exploit and manipulate them. The men of cloth and African traditional healers are both motivated by their egocentric reasons. The fictive world of Bulawayo's text uncovers some 
troublesome harsh realities of the present Zimbabwean society. The bogus prophets or diviners and traditional healers are fraudulent with the quest for survival in a country hit by economic and political crises. The following inscription is evident to this egocentric culture that prevails in contemporary Zimbabwe. Vodloza who is a self-proclaimed traditional healer in an impoverished slum and ironically named shanty town, Paradise has a huge sign erected at his shack with the following inscription:

\begin{abstract}
Vodloza, BESTEST Healer in all of this Paradise and beyond will proper fix all these troublesome things that you may encounter in your life: Be-witchedness, curses, bad luck, whoring spouses, childlessness, poverty, joblessness, AIDS, madness, small penises, epilepsy, bad dreams, bad marriage, competition at work, dead people terrorising you, bad luck with getting visas especially to USA and Britain, nonsenseful people in your life, Things disappearing in your house etc. etc. etc. Please payment in FOREX ONLY (Bulawayo, 2013:27).
\end{abstract}

The passage reveals the swindler character of Vodloza who is poor himself but ironically claims to provide solutions to poverty and joblessness. He cannot secure a job to feed himself first. This underlines the naivety of his followers who seem to be uncritical of the healer's conditions of living. Similarly, Prophet Bitchington Mborro exploits his followers who cannot get healthcare services due to the collapse of health infrastructure and delivery system in Zimbabwe. This offers the bogus prophet a conducive avenue for his scrupulous activities, Mborro demands, "two fat white virgin goats and five hundred US dollars" for his cleansing prayer sessions (Bulawayo, 2013: 99). Both Prophet Mborro and Vodloza are prevaricators who take advantage of the suffering citizens. Their crookedness reveals egocentric culture that disregards humanist ethics of fellow-feeling, compassionate for those in pathetic situations. Mborro, just like Soyinka's protagonist Jero in The Trials of brother Jero, has embarrassing carnal weaknesses. The ineffable name of the prophet augments the follies of this character whose gullible flock watches him touching "the thing"of a woman during the church service. The unbecoming behaviour of prophet Mborro in the presence of his followers underscores the ungodliness of this character and magnifies his shortcomings.

Trickery at its most treacherous is apparently conveyed in this passage. The information gathered is used to impress unsuspecting people who visit the bone thrower for spiritual help. Through these characters, the novel uncovers the shortcomings of religious practitioners whose wayward behaviour is baffling as they use charisma to swindle the subaltern of the postcolonial state. These characters have lost their conscience and have adopted survival of the fittest philosophy. Even the men of the cloth who are supposed to be models of moral uprightness have lost the moral sense of what is right and wrong. Mborro's selfishness is exposed when he demands forex from a family that is very poor and in extreme distress. What is most troubling is that both Christianity and African Indigenous religion are corrupt and exploitative, a scenario that heightens and reinforces degeneration that pervades all facets of life in postcolonial Zimbabwe. The irony is that religion is another site of subalternity instead of the expected godliness of the church, the flock is exploited and abused.

\title{
Aesthetics and vulgarities of power
}

Bulawayo's novel We need new names fictionalises the vulgarities of power during Mugabe's reign. Ordinary citizens have been reduced to scavengers due to ruling party's misgovernance and autocracy, Children from Paradise which is an urban slum, hunt for guavas to feed themselves. Darling narrates the fate of these children:

There are guavas to steal in Budapest, and right now l'd rather die for guavas. We didn't eat this morning and my stomach feels like somebody just took a shovel and dug everything out (Bulawayo, 2013:3).

What is most worrisome is that the parents of these children have resigned to their subaltern condition because Darling and her friends observe that: 
Getting out of Paradise is not so hard since the mothers are busy with hair and talk, which is the only thing they ever do. They just glance at us when we file past the shacks and then look away. We don't have to worry about the men under the jacaranda either since their eyes never lift from the draughts. (Bulawayo, 2013:3).

Paradise is a site of marginality suffered by its inhabitants who are violently secluded from the national politics by the Mugabe regime. The novelist employs juxtaposition to convey appalling the presence of social classes in Zimbabwe, a scenario that contests the narratives of egalitarianism in postcolonial African states. Budapest is an affluent suburb different from a Paradise which is a "kaka" that is a condemned and despised place. (Mavengano and Hove, 2019). The kakaness of Paradise is encoded in the presence of shacks, filthy surroundings, dirt children in rags, scrupulous activities, disease and death. The descriptive details of the slum Paradise, reveals what Agamben (1998) refers to as bare life, meaning a worthless and condemned life of the subaltern. The inhabitants of Paradise who are subjects to the sovereign power occupy a site of desolation. Yet, life is very different for the residents of Budapest:

\begin{abstract}
Budapest is big, big houses with satellite on roofs and neat gravelled yards or trimmed lawns, and the tall fences and the durawalls and the flowers and the big trees heavy with fruit that is waiting for us since nobody around here seems to know what to do with it It's the fruit that gives us courage, otherwise we wouldn't dare be here. I keep expecting the clean streets to spit and tell us to go back where we came from (Bulawayo, 2013:4).
\end{abstract}

This quote remarkably presents some critical details that help us understand the plight of Paradise inhabitants. This character understands her peripheral position and is critical of the apparent economic and social differences. Budapest is a site that speaks of the persistent remnants of colonialism. It is a site where the colonial logics of us/them still prevail and define the residents of this area. The perplexing dichotomy between Paradise where the poor blacks live and Budapest which is an affluent suburb speaks about class divisions, exclusionary practices and the falsity of utopian discourses of independence and de-colonisation. The novel ascribes a voice to the subaltern to speak for themselves and uncover sad realities of the postcolonial complexities obscured in sanitised narratives of independence and self-rule. Through this presentation, the novel articulates a plurality of consciousness, to brought from Bakhtin's (1981) thoughts, the subaltern voice presents its own world. We begin to understand the multiple realities of the national space which has the world of the poor and that of the middle class section.

It is critical to note that in postcolonial Zimbabwe, whites who remained in the country become victims of the ruling party's scapegoat and divergent politics. The white minority occupy marginal locale in the politics of mis/representation by the ruling party. A white man in Budapest becomes a victim of the ruling party's violent machinations. When the white man is violently evicted from his home by the 'third Chimurenga' he responds, "I am an African... This is my fucking country too, my father was born here, I was born here just like you." (Bulawayo, 2013:121).

The novels presents political suppression as one of the key thematic threads. One of the Paradise residents Bornfree, who supports the opposition party is brutally attacked and killed by members of the ruling party. His death speaks about gross human rights violation, political intolerance, and the vulgarity of power in the hands of brutal postcolonial politicians who cannot tolerate political opposition. The political landscape in Zimbabwe is highly polarised and troubled. Supporters of the Movement For Democratic Change (MDC) which is an opposition party are called white men's friends and "sell-outs, paid by "America and Britain" (Bulawayo, 2013:141).The death of Bornfree inscribes subaltern status to the inhabitants of Paradise who are silenced and denied voice in the national politics (Mavengano and Hove, 2019). The horrific act of beating and killing speak about vulgarity and coercion or performativity of power by the Mugabe regime (Mbembe, 2001/2003). The autocrat exercises 
absolute power and imposes political muteness on the agitated citizens who revolt against the ruler in the same way colonial masters exercised power over the colonised indigenous black people. Zimbabwe African National Union Patriotic Front (ZANU PF) government is not ready to relinquish power hence it violently silences such acts of subaltern speaking against the regime. Bulawayo's text exposes the troubling persistence of authoritarian rule in postcolonial era.

The postcolony replicates the colonial semantics of power and the subjects of power suffer from the uncertainty of hope, (Tagwira, 2006), because the postcolonial nation is a place of misery. The death of Bornfree significantly reveals how the regime has deployed violent machinery to silence the subaltern close to five decades in Zimbabwe. Actually, this act of violence against dissenting voices is an effort to intimidate and muzzle citizens. Paradise becomes a marginal site of political subalternity where citizens are denied voice to speak to the authorities. The most disturbing scenario is the loss of speech that is terribly suffered by the Paradise inhabitants after their hope to remove the ruling party from power through elections is dashed. Men from Paradise lower their heads and bend their backs in a symbolic gesture of submission to the regime's tyrant and totalitarianism.

The death trope has multiple semantic implications. It reflects the paradox of independence without freedom of speech to speak back to power. On one hand, his death inscribes restraints and silence from a monolithic political institution in Zimbabwe. The ruling party's monologic tendencies that viewed Mugabe as "one centre of power" and "president for life' are interrogated. The oppressive Zimbabwean regime thrives on impoverishing and enslaving the mind of the common man. The young African generation that must represent fresh ideas is corrupted and poisoned by egocentric politicians. We need new names strongly castigates the Zimbabwean government for victimising and pushing some citizens to the periphery. The ruling party defines who belongs to the "independent" Zimbabwe and who does not. Zimbabweans are projected as a monolithic mass of the ruling party's loyalists. NdlovuGatsheni (2009) problematises the term Zimbabwean in the contemporary era which he argues is loaded with biased political innuendoes of the regime in Zimbabwe. This qualification Zimbabwean excludes "perceived" opposition members who then become "bastardised" citizens, a name given to one of the children born and raised in the eponymous location called Paradise. These citizens lost their right to be called Zimbabweans. Their illegitimacy is punctuated in phrases such as "puppets of the west," "MDC hooligans" and "opposition criminal elements," used during the Mugabe and post-Mugabe periods.

The novel unravels the sad continuity of colonial logics of power and coloniality of being in Zimbabwe under the leadership of Mugabe. Paradise is a site of subalternity in Spivakan sense, which is ridden with squalor, poverty, political and sexual violence, AIDS-related deaths, disease, hunger, trickery, despair among other vices. The deliberate name-calling of dissenting voices is purposeful. "Hooligans" and "criminals" are a threat to "peace loving citizens" therefore the sovereign justifies its brutal clampdown and use of raw power on such "criminal elements" of the opposition party. The motifs of absolute power, repression and torture remind us of Achebe's (1987) Anthills of the Savannah. This is in conflict with the rhetoric of peace and unity conveniently utilised by the ruling party in 2018 harmonised elections. The novel unmasks a troubling nation space which remind us of an argument made by Ndlovu- Gatsheni (2013a) who contends that post-independence discourse is laden with myths and illusions of freedom. Yet, the novel shows subdued acts against the dominant culture by the subaltern classes. In this way the subaltern subjects claim voice though it is inaudible.

In another incident in the novel black Zimbabweans are violently evicted from their homes. Darling is traumatised by her experience of Murambatsvina and she narrates:

I dream about what happened back at our house before we came to Paradise.

I try to push it away but the dream keeps coming and coming like bees, like rain, like the graves at Heaven way (Bulawayo, 2013: 65). 
The dream is a flashback of the state-led evictions of black urbanites. Reference to the graves underscores memories of grief and death. The evicted people later live in a slum they deliberately name Paradise, under pitiable conditions. The child remembers "men driving the bulldozers laughing and she hears adults saying, Why, why, why, what have we done, what have we done, what have we done?" Victims of Operation Murambatsvina further say:

They shouldn't have done this to us, no, they shouldn't have. Salilwel' ilizwe leli, we fought to liberate this country. Wasn't it like this before independence? Do you remember how the whites drove us from our land and put us in those wretched reserves? I was there, you were there, wasn't it just like this? (Bulawayo, 2013:75)

The extract conveys deep cynicism about independence and its meaning for the ordinary people. Rhetorical questions and intra-sentential code-switching capture the disbelief and shock caused by the events unfolding in post-colonial Zimbabwe. The rhetorical question captures the sad scenario of aborted dreams and heightens the troubling fate of postcolonial subjects. Those who support the opposition parties, especially the Movement for Democratic Change (MDC), are brutally assaulted and killed. The national space is strictly regulated by the state.

This dictatorial power limits individual's autonomy. Mbembe (2010) rightly points out that the autocratic can abolish or grant liberties in the postcolony. Opposition members who defy the regime are punished by death. In this respect, the regime's monolithic narrative becomes the ultimate word, absolute truth that rejects polyvocality and polysemanticism. His assassination significantly speaks about the fate of ordinary Zimbabweans who cannot remove the repressive regime from power. Ordinary people are denied political agency by the necropower and have become "zombified citizens" (Mbembe, 1992/2001a). However, through dialogic and polyphonic stylisations in the novel the text presents subversive plurality of consciousness. Bornfree's political activism and death also speak about his determination to "speak back to power" (Madonsela, 2017; Mavengano, 2020). His political martyrdom resists the oppressive regime that strives on brutality and coercion. Thus, Bulawayo's novel contributes to the protest tradition in Zimbabwean literature. The novel privileges the urgency of the subaltern who refuses to be the objects of consciousness imposed by the regime. The subaltern seeks voice even from their position of subalternity. Paradise becomes a site of contestation, its inhabitants refuse to be part of muted groups. The killing of the opposition members conveys political polarisation and the government's attempts to stultify alter/native narratives (Nyambi, 2013). Mavengano (2020) argues that even the post Mugabe era has also seen the emergence and entrenchment of polarities between official discourse and the realities of the charged politics in Zimbabwe.

The narrator mocks politicians in Zimbabwe who thoughtlessly label the members of the opposition party and the west "enemies of the state." The regime in Zimbabwe misinforms the nation through scapegoating and divergent politics. The authorised state discourse creates and promotes racial tensions that are ironically similar to those fomented during the colonial period. The post-colonial paradoxes are explored. It is quite disturbing to note the dichotomy between political rhetoric and existential realities of the post-colony. The leader of the third "Chimurenga fighters" says this when his group attacks a white couple in Budapest:

\footnotetext{
Somebody please tell this white man here that this is not fucking Rhodesia! (...) Know this, you bloody colonialist, from now on, the black man is done listening, you hear? This is a black man country and the black man is in charge now. Africa for Africans only (Bulawayo, 2013:118).
}

The Third Chimurenga fighter also screams, "Kill the Boer, the farmer, the khiwa! Strike fear in the heart of the white man!" (Bulawayo, 2013:111). The above scene ensconces violence against whites. Most apparently, here is reverse racism in post-2000 era in Zimbabwe under the leadership of Mugabe. The Chimurenga fighter constructs a narrative of postcolonial 
humanity that is very limited in scope. This narrative conveys a sad persistent coloniality that privileges us/them logics in the conceptualisation of African humanity.

\title{
The paradox in typonymic term Paradise.
}

The typonymic stylisation together with juxtaposition are employed to articulate the anguish and disappointment suffered by residents of poverty-stricken Paradise. Paradise becomes a symbol of state failure. An imagined post-independence state which is characterised by hunger, violence, squalor and death. The narrator bemoans the fate of the postcolony in the following passage:

\begin{abstract}
When things fall apart the children of the land scurry and scatter like birds escaping a burning sky (...) Look at them leaving in droves despite knowing they will be welcomed with restraint in those strange lands because they must not sit comfortably lest they be asked to rise and leave, knowing they will speak in dampened whispers because they must not leave footprints on the new earth lest they be mistaken for those who want to claim the land as theirs. Look at them leaving in droves arm in arm with loss and lost, look at them leaving in droves (Bulawayo, 2013:145-146).
\end{abstract}

The above quote vividly depicts an apocalyptic image of the postcolonial period in Zimbabwe. The nation space is awfully scary to an extent that citizens flee in huge numbers. Most importantly, the novelist utilises hyperbole to foregrounds mass migration and deliberately avoid direct condemnation of the autocratic regime that has caused the "falling apart of things." Instead, the narrator rather laments over the conditions of the subaltern subjects. The political context in Zimbabwe limits artistic freedom of expression. Yet, at the same time, the semantic ambiguity here is employed as artistic arsenal to attack the ruling party in Zimbabwe for creating harsh conditions of living for the common citizens. The most disturbing scenario is that in foreign spaces, migrants who flee the unhomeliness of their country loss their communicative freedom because they begin to speak in "dampened whispers." This echoes inscribed in/visibility (Mavengano, 2020).

Paradise becomes a metonymic locale that conveys the unhomeliness of the home country during Mugabe's tenure. The kaka trope is laden with the quest for a rebirth and reforms in the nation space. The term kaka that is used to describe everything that is undesirable in the postcolonial era in Zimbabwe also underscores the ambiguities embedded in the discourses of self-rule or black rule and independence. It is apparent that what comes after protracted struggle could be metaphorically described as a harvest of thorns (Mavengano, 2020). The novel registers frustration with flag independence that does not gain the common citizens. Thus, the kaka trope reflects unfulfilled dreams of poor Zimbabweans and the failures of postindependence society. Political freedom without the economic change among those previously oppressed is inconsequential and empty. The novel gives prominence to Zimbabwe's religious and socio-political problematics as well as the daunting ordeals and anguish of those who fled from the misery and "wretchedness" of their motherland. Reminiscences and flashbacks are constituent parts of the narrative techniques employed to present extremely touching accounts of the sufferers.

Bulawayo's novel We need new names contests and subvert narratives constructed by the state meant to obscure the failures of the government. In its vocative and phatic functions, the narrator's voice presents tonalities of rage and angst in order to subvert the government's grand master narrative. The novel We need new names unmasks the intricacies and vulgarities of power as well as religious charlatanism in the postcolony.

Postcolonial subjects are symbolically naked, stripped of human dignity just like the pictures of 'hungry looking children' from Paradise who are in "tattered clothes," or pictures of a ten year pregnant girl Chipo. 'The image of children from Paradise with "black naked buttocks becomes a metaphor of the sad story of the postcolonial subjects whose inescapable poverty is comparable to that of the biblical Lazarus or Fanon's (1963/2001) description of the 
wretched of the earth. Not my buttocks, not my dirty clothes, but me" The child captures in pictures in the novel We need new names, is aware of the dehumanisation of the poor just like the subaltern in the postcolony. Interestingly, children criticise the inhumane treatment they are exposed to by the NGO whose disdainful attitude is visible because they do not want to be anywhere close to the dirty, hungry-looking children from Paradise slum. In a similar case of poor racial relations, Darling tells us about her ordeal at Washington High School in America:

\begin{abstract}
When I first arrived at Washington, I just wanted to die. The other kids teased me about my name, my accent, my hair(...), it kept going and going so that in the end I just felt wrong in my skin, in my body, in my body, in my clothes, in my language, in my head, everything (Bulawayo, 2013:165).
\end{abstract}

The use of parataxis in this passage stirs the audience's attention, highlighting an endless list of things that Darling is teased about because she is a black African immigrant. African immigrants are the subject of mockery and Tom, a young male immigrant, commits suicide because he is constantly tormented by white children who call him a "freak." This captures the painful manifestation of racism in the present day world of the globalised universe. Together, these passages reveal an important reading about the complex race relations characterising the globalisation metanarrative. It is in this context that we notice the need for continued examination of racial relations in the contemporary globalectics. The pathetic position of a white couple whose home is ransacked by the Third Chimurenga fighters in We Need New Names, however, highlights a new dimension of reverse-racism. The rampage bespeaks the helplessness and insecurities of whites in post-2000 Zimbabwe. Former President Mugabe seems to have forgotten his inaugural speech:

If yesterday, I fought you (whites) as an enemy, today you have become a
friend and ally with the same national interest, loyalty, rights and duties as me
(...) The wrongs of the past now stand forgiven and forgotten (Mugabe, 1980).

This inaugural speech defined a new nation with a new philosophy towards racial harmony and respect for the rights of the citizens. Yet, in the post-2000 era when Mugabe and his party faced an increased crisis of legitimacy, the country witnessed palpable autocracy set on the palimpsest of a self-serving political culture. The nation became a divided land (Mavengano, 2020) and ruling party strives on what Ndlovu-Gatsheni (2008) calls politics of inclusion and exclusion. The politicians from the ruling party re-enacted and repeated racist discourses in economic, political and social domains to justify brutality against whites who were falsely accused of supporting a "British's puppet" opposition party, the MDC. It is an irrefutable fact that the ruling party seeks legitimacy and refute political change in discourse of entitlement. Entitlement narrative is entrenched in state's semiotics and mechanisms of power. The discourses of entitlement are exclusionary and meant to deny opposition parties to ever rule Zimbabwe (Mavengano, 2020). Thus, the country's colonial past became a useful archive for the political ideological structure to maintain the status quo.

Whites in Zimbabwe became an easy chromatic scapegoat. It is not an overstatement to say that the ruling party abuses power and employs intimidation strategies to muzzle increasing political dissent where racism is purposely choreographed to re-enact the colonial schisms of lore. When Zimbabweans felt cheated in the post-2000 elections and contested the legitimacy of the ruling party, the state increased the tensions through coercive tactics and marginalisation of some sections of the society, thereby highlighting Black Nationalism in crisis. White minority and opposition members became the perceived "others" and unwanted enemies of the state. The nation took a step back to adapt colonial oppressive practices and some of these were perfected to the satisfaction of the postcolonial oppressors.

\title{
Enclosing
}

The study focused on thematisation of religious charlatanism and vulgarities of power in the postcolonial state as depicted in the fictive writing of Bulawayo, a Zimbabwean author. The 
reading of the text from postcolonial theorisations revealed that those in corridors of power promote self-serving political culture that imposes muteness and subalternity. The novel laments dashed hopes for improved living conditions in postcolonial era. Religious also exposes egocentric culture which is one of the undesired traits of the postcolonial state that has emerged in Zimbabwe. The promise of the rebirth of a nation that was hoped for when Zimbabwe attained independence four decades ago is not yet witnessed.

\section{References}

Achebe. C. (1958). Things Fall Apart, New York: Heinemann.

Achebe. C. (1987). Anthills of the Savannah, London: Heinemann.

Agamben, G. (1998). Homo sacer: Sovereign power and bare life, (Trans. Daniel HellerRoaen) Stanford, Stanford University Press.

Bakhtin, M. M. (1981). The Dialogic Imagination. Austin: University of Texas Press.

Bhabha, H. (1994). The location of culture, London: Routledge.

Fanon, F. (1963/2001). The Wretched of the Earth, London: Penguin Books.

Javangwe, T. D. (2014). Vulgar acts of entrenchment: The depiction of the Zimbabwean postcolony in Chenjerai Hove's Palaver finish, Imbizo, 5(1), 60-70.

Mavengano, E. \& Hove, M. L. (2019). "Kaka country: An intertextual reading of nation dysfunction in Bulawayo's We Need New Names and Jinga's One Foreigner's Ordeal." Literator, 40 (1), a1595, https://doi.org/10.4102/lit.v40il.1595.

Mavengano, E. \& Hove, L. M. (2020). "The translingual subjects: Shaping identities and deconstructing rainbowism" in One Foreign Ordeal, Literator, 41(1), 1-11.

Mavengano, E. (2020). A Comparative stylistic Analysis of selected Zimbabwean and South African fictional narratives 2000-2015 published PhD Thesis, North West University.

Mbembe, A. (1992). The banality of power and the aesthetic of vulgarity in the colony, Pubic Culture, 4(2), 1-30.

Mbembe, A. (2001a). On the postcolony. Berkeley/ Los Angeles: University of California Press

Mbembe, A. (2003a). Necropolitics, Public Culture, 15(1), 11-40.

Ndlovu-Gatsheni, S. J. (2008). Patriots, puppets, dissidents and the politics of inclusion and exclusion in contemporary Zimbabwe. East African Social Science Research Review, 24(1), 81-108.

Soyinka, W. (1964). The Trials of Brother Jero in The Jero Plays, Ibadan: Spectrum Itd pp.745.

Spivak, G.C. (1988). "Can the Subaltern Speak?” In C. Nelson and L. Grossberg (eds) Marxism and the Interpretation of Culture, Urbana: University of Illinois Press.

Spivak, G. C. (2005). Scattered Speculations on the Subaltern and the Popular." Postcolonial Studies, 8(4), 475- 86. [Available online at https://doi.

Org/10.1080/13688790500975132]

Tagwira, V. (2006). The Uncertainty of hope, Harare: Weaver Press. 
Pharos Journal of Theology ISSN 2414-3324 online Volume 102 - Special Ed 2 (2021) 